\title{
Holokauszt-oktatás multimédiás eszközök segítségével
}

\section{A Dél-kaliforniai Egyetem Soá Alapítványának videóarchíuma} közel 53000 holokauszt túléló, embermentó és táborfelszabaditó interjúját tartalmazza, amelyek felhasználása új távlatokat nyitott meg a holokauszt oktatásában. Az alábbi tanulmányban szó esik a videóinterjúk használatának pedagógiai céljairól és elónyeiról

a hagyományos oktatáshoz képest. Az MTA-SZTE Elbeszélt

Történelem és Történelemtanítás Kutatócsoport által végzett kutatás azt vizsgálja, hogy a történelmi emlékezet és a multimédiás eszközök beemelése a 20. századi traumák oktatásában milyen képességeket és attitúdöket tud kialakitani a diákok oktatása során. A kvantitatív és kvalitatív mérések eddigi részeredményei is arra utalnak, hogy az empátia, a társadalmi tolerancia és szolidaritás, a felelósségérzet és a kritikus gondolkodás készségeinek fejlesztésére a multimédiás eszközök kiválóan alkalmazhatók.

\section{Bevezető}

A z oral history források történelemtanításba való bevonása, a múltról szóló személyes narratívák tantárgy-pedagógiai szempontok szerinti alkalmazása tudományos kutatási tényekkel igazolt módon fontos hozzáadott értékkel bír a történelemoktatásban (Husbands, 1996; Nora, 1996; Bage, 1999; Farmer és Cooper, 1998; Keating és Sheldon, 2011; Körber, 2011; Levtis és Barton, 2011; Jancsák, 2018; Kojanitz, 2020. 18.).

A tanulmányban ismertetett kutatás vizsgálati alapját egy-egy kettéosztott tanulócsoportban tartott „hagyományos”, illetve „videóinterjús” tanóra képezi. Az MTA-SZTE Elbeszélt Történelem és Történelemtanítás kutatócsoport (az MTA Tantárgy-pedagógiai Programjának támogatásával) kutató-fejlesztő feladatvállalásaiban egyrészt a történelmi emlékezet fontosságát hangsúlyozza a traumák kollektív feldolgozásában, másrészt a multimédiás és digitális anyagok jelentőségét emeli ki a mai diákok számára. A csoport tagjai olyan tananyagokat fejlesztenek, amelyek a digitális eszközök segítségével nem kizárólag a kerettantervi adatok megtanítását célozzák, de a múlt történéseinek megismertetésével a diákok empátiáját, toleranciáját, kritikus gondolkodását, demokráciára való fogékonyságát szeretnék fejleszteni. Írásomban a holokauszt tantárgyi témát kutató csoport tagjaként számolok be az eddigi tapasztalatokról és kutatási eredményekről. A tanulmány empirikus alapját jelentő kutatási adatok felvétele három iskolában történt, videóinterjús tanórán (78 fó) és hagyományos, tankönyvvezérelt tanórán (59fö) részt vevő diákok, illetve tanáraik körében. Alapvetően a videóinterjús órák tapasztalatait 
összegzem, és csak bizonyos esetekben térek ki a nem videóinterjús órákkal való összehasonlításra.

A kutatásban általam fejlesztett és használt tanórák témája közelebbröl a jogfosztás fokozatosságának, vagyis a holokauszthoz vezető lépéseknek a bemutatása volt. A videóinterjús órában öt interjú köré épült az óra. A klipek a törvényi diszkriminációról, a sárga csillagról, a gettósításról, a deportálásról és a koncentrációs táborról szóltak. A „hagyományos” (vagyis nem multimédiás) óra ugyanezt a témát járta körbe, de ott a videóinterjúk helyett írott forrásokat (pl. a nürnbergi törvények szövegét) használtam fel. A tanórákat 11., illetve 12. évfolyamos diákokkal végeztem; mind a multimédiás, mind az írott források értelmezésekor egyéni, páros és osztálykeretben történö interaktív módszerrel dolgoztunk. Az osztályokat kettébontottam, az egyik felének a „,hagyományos”, a másiknak a videóinterjús órát tartottam (ez körülbelül 17-17 főt jelent). Egyik tanulói csoporttal sem tanultunk még együtt a holokausztról, erröl iskolai keretek között legutoljára az általános iskola 7-8. osztályában, illetve a holokauszt emléknapokon hallottak. A tanulók az órák elött és után is kitöltöttek egy-egy kérdőívet, amelyek kvantitatív felmérés céljából készültek. Ezen kívül csoportonként 3-3 diákkal az órák után fókuszcsoportos beszélgetés is zajlott kvalitatív mérés céljából. Más tananyaggal, de ugyanilyen struktúrában folytak az órák két másik iskolában is a 2019-2020-as évben.

A multimédiás eszközt használó videóinterjús tanórák alapját esetemben a Dél-kaliforniai Egyetem Soá Alapítványának (University of Southern California Shoah Foundation, USC SF $)^{1}$ videóarchívuma képezi, amely körülbelül 53000 interjút tartalmaz túlélőktől, szemtanúktól, embermentőktől a holokauszthoz kapcsolódóan. Továbbá felhasználtam azokat a módszertani tapasztalatokat, amelyeket a Zachor Alapítvány ${ }^{2}$ tananyagfejlesztő munkatársaként szereztem az elmúlt 8 évben.

\section{A videóinterjúk használatának előnyei}

A tanári szemléltetőeszközök tárháza igencsak kibővült az elmúlt évtizedekben, és haladnunk is kell a korral, mert a mostani tanulói generációkat sokkal több (vizuális, audiális, stb.) inger éri, mint korábban bármikor. Első ránézésre a videóinterjú csak részben felel meg ennek az elvárásnak, hiszen ugyan vizuális és audiális forrás, de nem veheti fel a versenyt pl. egy gyors, csillogó online feladattal. Ennek ellenére az volt az elözetes feltevésünk, hogy a videóinterjúk használata többek között nagyobb élményt nyújthat a diákok számára. A kutatás posztkérdőívében megadott válaszok szerint a videóinterjús tanóra valóban jobb eredményt ért el e tekintetben, mint a hagyományos (1. ábra). 
mennyire tanultál újat?

mennyire változatos?

mennyire tanulságos?

mennyire érdekes?
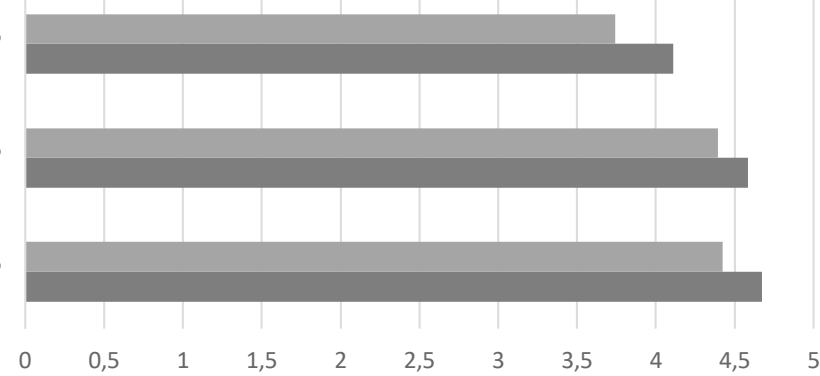

nagyományos videós

1. ábra. A videóinterjús és ,hagyományos” óra értékelése a diákok szerint. $1=$ egyáltalán nem, $5=$ nagyon. Az 1-5 közötti számok átmenetet jelölnek. Adatok forrása: MTA-SZTE ETTK

A kvantitatív mérés adatait kiegészíthetjük a kvalitatív mérés szerinti, azaz a fókuszcsoportos beszélgetésben elmondottakkal. A válaszokban megfigyelhetjük, hogy mi az, ami miatt a diákoknak élményt jelentett a tanóra:

„Ezek a sztorik engem mindig így megérintenek...” (12. oszt.)

„A videóinterjúk hordoznak egy ilyen mintát [...] egyéni történetekből összeáll egy ilyen minta [...] az hazavihető, hogy velük mi történt, hogyan cselekedtek." (12. oszt.)

„Az a jó, hogy ilyenkor amikor videóinterjú van, akkor szinte rögtön kényszerül az ember belehelyezkedni abba, amit elmondanak, és így sokkal könnyebben fenn lehet tartani szerintem a figyelmet." (12. oszt.)

A diákok válaszaiból az is kiderült, hogy bizonyos kérdések a tanórák után is foglalkoztatták a diákokat, beszéltek róla az osztálytársaikkal, esetleg otthon a családdal, vagy legalább magukban sokat gondolkoztak egy-egy problémán, vagyis mindenképpen részesültek egyfajta affektív (érzelemalapú) tanulásban.

„Hogy ezt hogy tudták így végigcsinálni?” (12. oszt.)

„Mi az, ami miatt mégis folytatni tudták?” (12. oszt.)

„...nem csak egy történelmi esemény [...] annyira nem is távoli [...] hatása van a mára is..." (12. oszt.) 
A kvantitatív mérés adataiból is az derült ki, hogy a diákok többsége az osztálytársaival, több mint egy harmada pedig a családtagjaival beszélgetett a holokausztról (1. táblázat):

1. táblázat. Óra utáni beszélgetés a holokausztról.

\begin{tabular}{|l|c|}
\hline A videóinterjús tanóra után, az azóta eltelt időszakban beszélgettetek-e a holokausztról \\
\hline osztálytársakkal & $61,8 \%$ \\
\hline családtagokkal & $35,3 \%$ \\
\hline
\end{tabular}

Adatok forrása: MTA-SZTE ETTK

Érdemesnek tartom a fókuszcsoportos beszélgetés válaszait összevetni az online IWitness platformhoz ${ }^{3}$ kapcsolódó kérdőív válaszaival. Az IWitness a Dél-kaliforniai Egyetem Soá Alapítványának digitális oktatási platformja, amelyen többek között videóinterjúkra épülő feladatok találhatók. Az itt található feladatokhoz kapcsolódó kérdőívek nagyobb merítéssel rendelkeznek, jelenleg több száz diák adatai állnak rendelkezésünkre. Ez a típusú kérdóív nyitott mondatokat tartalmaz, vagyis a diákoknak kell befejezniük a megkezdett mondatot. A mi témánk szempontjából releváns kérdés most az, ami úgy kezdődik, hogy „A videóinterjúk hozzásegítettek ahhoz, hogy...”. Ennek a mondatnak a befejezése szinte minden esetben kiemelte a videóinterjú érdekességét, azt a jellemzőjét, hogy közel hozza a diákhoz az óra témáját, a történelmi eseményt:

„...az emberi oldalát is megismerjük a néha száraz faktológia által átszőtt táblázatoknak..."

„Ne legyen monoton, unalmas az anyag elsajátítása.”

„Élvezetesebb és emberibb legyen a tananyag, nem csak számok és statisztikák voltak, hanem emberek és életek."

„Mindenképp érdemes meghallgatni ilyen interjúkat, mert sokkal hitelesebbnek hat ez az egész egy olyan ember szájából, aki ezt átélte.”

A fókuszcsoportos beszélgetés és az IWitness-es felmérés tapasztalatai tehát megerősítették a kvantitatív mérés eredményeit, miszerint a videóinterjúk használata valóban élményt nyújt a diákok tanulásában. Az a kétségünk, hogy a videóinterjúk nem eléggé „vibrálóak” ahhoz, hogy fenntartsák a mostani generációk érdeklődését, nem igazolódik. Persze ehhez fontos a videóklipek megfelelő kiválasztása és feldolgozása is. A személyes történetek, az egyéni perspektíva, a könnyü azonosulás az interjúalannyal („olyan, mintha a nagypapámat/nagymamámat hallgatnám", mondják a tanítványaim) azonban mindenképpen lekötik a tanulók figyelmét.

A videóinterjús tanórák általában nem azt a célt szolgálják, hogy a kerettanterv szerinti tananyagot, lexikális adatokat tanítsuk meg a diákoknak. Ez inkább előny, mint hátrány, hiszen éppen hogy segítheti a tankönyvi adatok jobb megértését, elmélyítését az, hogy több nézőpontot és értelmezési réteget ismertetünk meg a tanulókkal. Ezt alátámasztják a tanulói visszajelzések is, amelyeket olyan végzős diákok mondtak el, akik a holokauszt témáját videóinterjús tananyagokon keresztül tanulták:

„Személy szerint sok mindent hallottam már a holokausztról, de rengeteg érdekes dolgot tudtam még meg." 
„...amikor a múltról tanulunk és a múltban történt hibákról, akkor teszünk azért, hogy legközelebb ez ne forduljon elö. Az, hogy ezeket videó interjúkból tanultuk, azokkal együtt, még közelebb hozta szerintem és jobban átérezhetővé."

„Számomra az a tanulsága, hogy a holokauszt okozta fájdalmakat, veszteségeket sokkal jobban meg lehet ismerni, érteni egy-egy áldozat, család sorsán keresztül, mint csupán a számokból, ugyanis így tudjuk az egyes áldozatokat mint értékes emberek, anyák vagy apák, gyermekek, családtagok, látni, és nem egy hatalmas tömeg egy-egy tagjaként."

„Jó volt, hogy az órákon nem csak egy szempontból vizsgáltuk meg az eseményeket, hanem több szerep szerint. Az interjúk sokat segítettek benne, hogy még közelebb kerüljünk az eseményekhez."

\section{Pedagógiai célok}

Multimédiás tananyagok készítésénél vagy felhasználásánál a legfontosabb, hogy tanárként előre meghatározzuk, mik azok a pedagógiai célok, amelyek miatt videóklipeket szeretnénk beépíteni az órába. Vagyis hogy megállapítsuk, mi az, amiben egy videóinterjús tanóra többet nyújt a hagyományosnál, vagy miben célirányosabb annál - ami nem jelenti azt, hogy egy „hagyományos” (pl. írott forrásszövegekkel dolgozó) tanóra ne lehetne szintén érdekes és hatékony. A videóinterjús tanórának nem felváltania kell a hagyományost, hanem az lenne a kívánt cél, hogy stabilan gazdagítsa a pedagógiai eszköztárunkat.

A történelem tantárgyon belül különösen a holokauszt témájának tanítása kapcsán szoktuk hangsúlyozni, hogy annak tanulása és megértése - a történelmi emlékezet megörzése mellett - azért is nagyon fontos, hogy tanuljunk a múlt hibáiból, és ne engedjük, hogy újra megtörténjen. A holokauszt nem Auschwitzcal kezdődött, és a mai, demokratikus társadalmak számára is fontos tanulsága lehet annak, hogy mik voltak azok a lépések, amelyek odáig elvezettek. Ha tehát arra szeretnénk ösztönözni diákjainkat, hogy próbáljanak olyan attitüddel élni a világban, amely hozzájárul ahhoz, hogy a jövőben az efféle történelmi trauma elkerülhető legyen, akkor egyik pedagógiai célunk az, hogy
A történelem tantárgyon belül különösen a holokauszt témájának tanítása kapcsán szoktuk hangsúlyozni, hogy annak tanulása és megértése - a történelmi emlékezet megốrzése mellett - azért is nagyon fontos, hogy tanuljunk a múlt hibáiból, és ne engedjük, hogy újra meg-

történjen. A holokauszt nem Auschwitzcal kezdödött, és a mai, demokratikus társadalmak számára is fontos tanulsága lehet annak, hogy mik voltak azok a lépések, amelyek odáig elvezettek. Ha tehát arra szeretnénk ösztönözni diákjainkat, hogy próbáljanak olyan attitúddel élni a világban, amely hozzájárul ahhoz, hogy a jövóben az efféle történelmi trauma elkerülhetố legyen, akkor egyik pedagógiai célunk az, hogy aktiv állampolgárokat neveljünk belólük, vagyis empatikus, kritikusan gondolkodó, a társadalmi szolidaritást és az emberi jogokat tiszteletben tartó egyének legyenek. 
aktív állampolgárokat neveljünk belőlük, vagyis empatikus, kritikusan gondolkodó, a társadalmi szolidaritást és az emberi jogokat tiszteletben tartó egyének legyenek.

E némileg szubjektív lista elemei közül az egyik legfontosabb az empátia, a másokkal való együttérzés készségének fejlesztése. Empátia nélkül a társadalom szövete szétfoszlik, mivel minden egyén csak önmagában létezik, aki csak akkor emeli fel a szavát, ha őt magát éri igazságtalanság. Az egymástól elszigetelt egyének azonban nem tudnak hatékonyan működni (például az államhatalommal szemben), mert bizonyos társadalmi igazságtalanságokat csak szélesebb körü összefogással lehet legyőzni.

Az aktív állampolgár tulajdonsága a kritikus gondolkodás képessége, vagyis a propaganda manipulatív üzeneteinek felismerése, a „sorok között olvasás”, a történelmi és társadalmi helyzetek elemzésének készsége, az emberi vagy intézményi cselekedetek mozgatórugóinak megértése. Fontos emellett fejleszteni az emberi jogok és a demokrácia müködésének ismeretét, és ezek segítségével a társadalmi szolidaritásra nevelni a diákokat, hogy ne csak elméletben ismerjék fel a diszkriminációt, de konkrét esetekben is tudják azonosítani és a megfelelő lépéseket megtenni. Ezeket mind kívánatos fejlesztenünk a történelem tanítása során; kérdés, hogy a videóinterjúk alkalmazása miben segít ehhez hozzá minket.

Előzetes feltevésünk szerint a multimédiás források felhasználása azért hatékony e dolgoknak a megtanításában, mert a fentebbi, elméletben elsajátítható tényezőket személyessé teszi, ami nem csak az empátia fejlesztése szempontjából hasznos, hanem az affektív alapú tanulás révén a kognitív elemeket is mélyebb tartalommal tölti meg. Például törvényszövegek alapján is megtanítható, melyek pontosan az emberi jogok, és hogy a diszkriminatív törvények mitöl fosztanak meg egyes társadalmi vagy etnikai csoportokat. Azonban csak akkor érthetjük meg ennek teljes mélységét és következményeit, ha konkrét emberek konkrét élethelyzetéről hallgatjuk meg azoknak az elbeszélését, akik maguk is átélték ezt. Sok tanítványom teszi szóvá, hogy a videóinterjúk alapján értették meg igazán, mit jelentett a diszkrimináció, a jogfosztás, az intolerancia, az üldözés.

„Nekem azt [üzenik a videóinterjús történetek], hogy mennyire alapvetőnek veszszük a szabadságot [...] és hogy mennyire lekorlátozták [a zsidókat] egy teljesen irreális ok miatt.” (12. oszt.)

„...hogy felismerjük azt, hogy bármilyen általánosítás vagy kirekesztés mikor válik veszélyessé." (12. oszt.)

Az egyén szemszögéből vizsgált történetek segítik diákjainkat abban a felismerésben, hogy a múlt eseményei megtörténhetnek a jelenben velünk is. Ha ezt a kapcsolatot megértik, akkor talán a jövőben is arra törekednek majd, hogy felismerjék a jeleit annak, amikor egy társadalomban nem tartják tiszteletben az alapvető emberi jogokat, vagy nem érvényesülnek a demokratikus értékek.

Felmerülhet bennünk, hogy ha azt gondoljuk, ezek a készségek könnyebben fejlödnek a személyes élettörténetek és tapasztalatok megismerésével, akkor mennyiben lehet több a videóinterjús tanóra ahhoz képest, amikor például a tanár korabeli naplórészletet - írott dokumentumot - ismertet meg a diákjaival. Természetesen ez is nagyon hasznos és nem elhanyagolandó forrás - és valamikor nem is volt lehetőség másra technikai eszközök híján. A videóinterjú abban nyújt többet, hogy a diák látja az interjúalany mimikáját, gesztusait, érzelmi reakcióit, hallja a hangszínét és annak megváltozását. Ezek nem egyszerüen többletinformációt jelentenek a történetek megértése szempontjából, hanem fejlesztik a diákok érzelmi intelligenciáját, főleg, ha a tanár egy-egy kérdéssel, feladattal hangsúlyt is fektet ezek megfigyelésére. 
A videóinterjúk meghallgatása közben a diákjaink megismerkednek az interjúalanyok választási lehetőségeivel, dilemmáival. Különböző viselkedésformákat elemezhetnek, vitatkozhatnak az erkölcs, felelösség, tolerancia kérdéseiről. Az ilyen lehetőségek tárháza végtelen, amit az is bizonyít, hogy akár egyetlen 1 perces videóklip köré is több, egymástól eltérő tematikájú tananyagot építhetünk. Ez a fajta multiperspektivitás rendkívül hasznosnak bizonyul a kritikai gondolkodás fejlesztésében. A tanárok számára ugyanakkor az jelenthet kihívást az efféle tanórák levezénylésében, hogy ne ők maguk jelentsenek ki ex cathedra igazságokat, és megmondják, mi a jó és mi a rossz válasz, hanem engedjék a diákok szabad véleményalkotását.

Számos módszert alkalmazhatunk a videóinterjúk feldolgozására a tanórákon. Önmagában a videóinterjú csak egy multimédiás eszköz, amit a köré épített tananyag tesz igazán hasznossá. Ennek a tanulmánynak most nem célja a módszertani ajánlások körbejárása, általánosságban elmondható azonban, hogy a konstruktivista pedagógia metodológiája bizonyult eddig a legkézenfekvőbbnek, vagyis amikor a diák előzetes tudására és tapasztalataira építünk, és a tanulók maguk építhetik fel tudásukat, és ezáltal fejleszthetik személyiségüket is (Nahalka, 2013). A videóinterjúk beépítése a tananyagokba kiváló alkalom arra, hogy a tanulást sokkal tágabb keretek között értelmezzük, mint amit az oktatási-nevelési dokumentumok és elöírások megkövetelnek. A már említett IWitness online oktatási platform tananyagai például mind ezt az elvet követik, négy szakaszra bontva a különböző oktatási tartalmakat. Ez a négy szakasz a Ráhangolódás, Gyüjtőmunka, Jelentésteremtés és Reflexió szakasza (az angol eredetiben Consider, Collect, Construct, Communicate). Ennek a metódusnak a segítségével a diákok könnyebben megtalálják a kapcsolatot a múlt és a jelen, a történelem és önmaguk élete között (Mezei, 2019).
Számos módszert alkalmazhatunk a videóinterjúk feldolgozására a tanórákon. Önmagában a videóinterjú csak egy multimédiás eszköz, amit a köré épitett

tananyag tesz igazán hasznossá. Ennek a tanulmánynak most nem célja a módszertani ajánlások körbejárása, általánosságban elmondható azonban, hogy a konstruktivista pedagógia metodológiája bizonyult eddig a legkézenfekvóbbnek, vagyis amikor a diák elözetes tudására és tapasztalataira épitünk, és a tanulók maguk épithetik fel tudásukat, és ezáltal fejleszthetik személyiségüket is (Nahalka, 2013). A videóinterjúk beépitése a tananyagokba

kiváló alkalom arra, hogy a tanulást sokkal tágabb keretek között értelmezzük, mint amit az oktatási-nevelési dokumentumok és elöirások megkövetelnek. A már emlitett IWitness online oktatási platform tananyagai például mind ezt az elvet követik, négy szakaszra bontva a különbözó oktatási tartalmakat. 


\section{A kvantitatív mérés eredményei}

Az alábbiakban azoknak a társadalmi attitüdöknek az értékelésére fókuszálok, amelyeket a legfontosabb tanulói tulajdonságok és gondolkozás fejlesztésének véltem elözetesen. A videóinterjús órákat követő kérdöívekben rákérdeztünk a különböző társadalmi értékeknek, a történelemórákhoz általában köthető affektív és kognitív elemeknek, illetve a politikához vagy demokráciához kapcsolható attitüdöknek a jelenlétére, illetve arra, hogy ezek elsajátítását mennyire segítette a videóinterjús és a hagyományos tanóra. Néhol érdemes összevetni azt is, hogy a különböző értékek jelenlétét és fejlesztését az órán hogyan értékelik diákok (2. ábra) és tanárok (3. ábra).

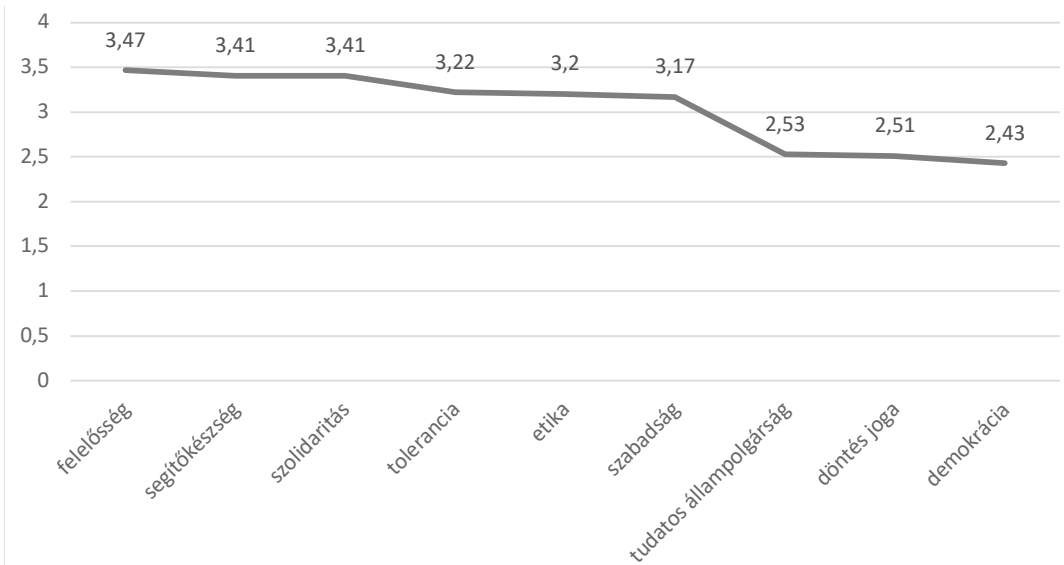

2. ábra. A videóinterjús holokauszt-tanórán megjelenö értékek a diákok szerint. $1=$ egyáltalán nem jelent meg, 5 = leginkább megjelent. Az 1-5 közötti számok átmenetet jelölnek. Adatok forrása: MTA-SZTE ETTK

Érdemes megtekinteni, hogy a tanárok hogyan értékelték ugyanezen értékek megjelenését az általuk tartott „hagyományos” és videóinterjús óra során:

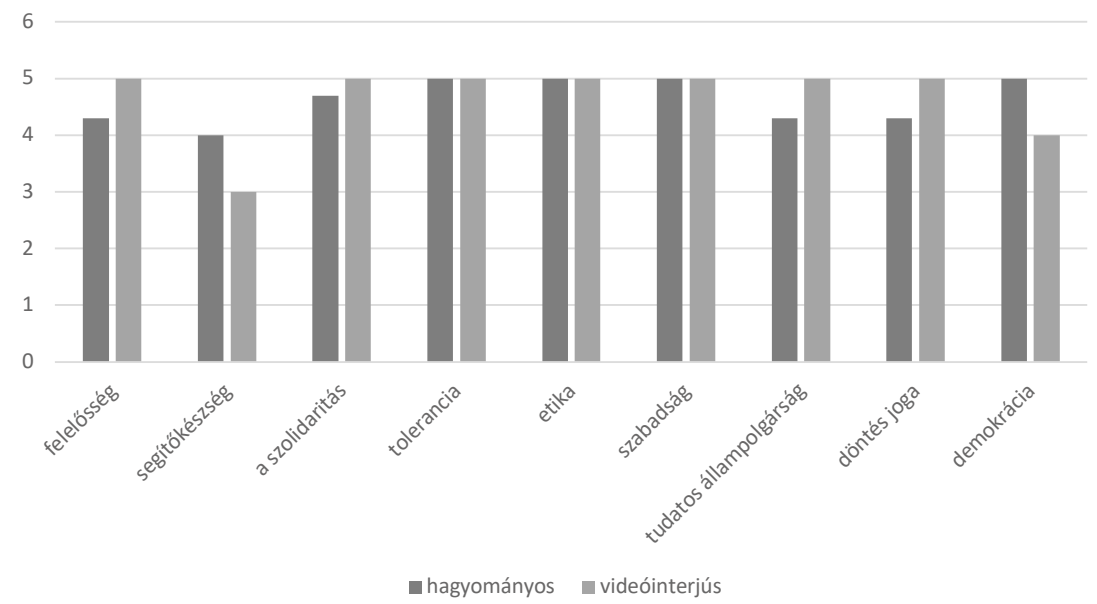

3. ábra. Mennyire jelentek meg ezek az értékek a hagyományos és a videóinterjús órán a tanárok véleménye szerint. 1 = egyáltalán nem, 5 = leginkább. Az 1-5 közötti számok átmenetet jelölnek. 
Az egyértelmủen kitűnik az eredményekből, hogy a tanárok szerint a multimédiás tanórán inkább megjelennek ezek a társadalmi értékek, többnek a maximális, ötös osztályzatot adták (3. ábra). Az egy-két eltérés abból is adódhat (például hogy a segítőkészség vagy a demokratikus értékek alacsonyabb osztályzatot kaptak), hogy mi volt az óra konkrét témája. Az inkább elgondolkodtató, hogy a diákok a tanároknál általában alacsonyabb osztályzatot adtak ezeknek az értékeknek (2. ábra). Ez azonban fakadhat a tanári tudatosságból - jobban meg tudják fogalmazni, milyen értékeket akarnak közvetíteni az órákkal -, illetve azt sem szabad elfelejtenünk, hogy a diákok által adott osztályzatok sem alacsonyak. Mindenesetre a későbbi tananyagfejlesztés során érdemes megfontolnunk, milyen módszereket alkalmazzunk a multimédiás források felhasználásához, ha azt szeretnénk, hogy ezek az értékek még inkább megjelenjenek az órákon.

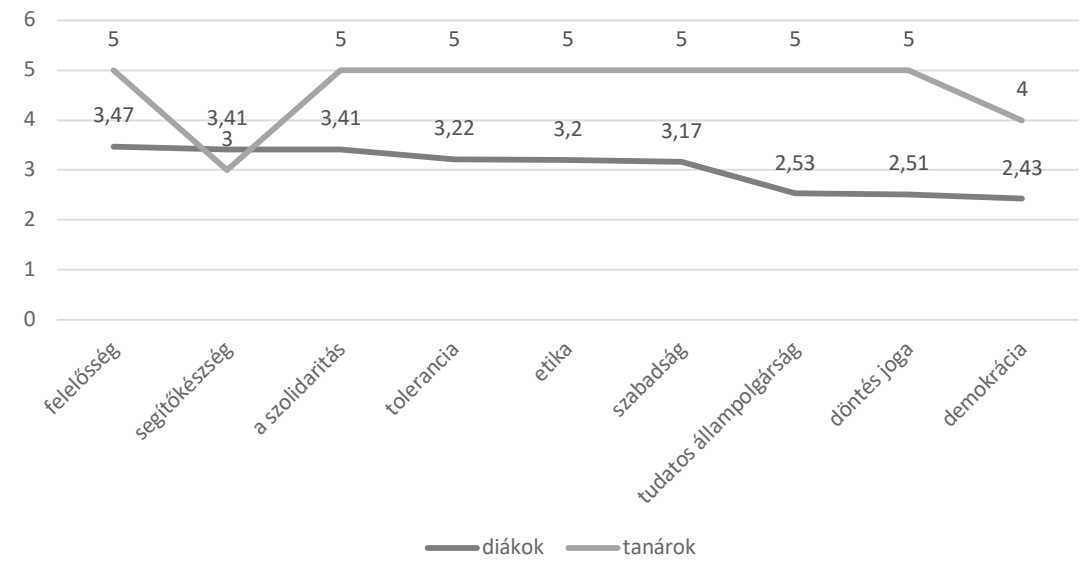

4. ábra. Mennyire jelentek meg ezek az értékek a videóinterjús órán a diákok és a tanárok véleménye szerint. 1 = egyáltalán nem, 5 = leginkább. Az 1-5 közötti számok átmenetet jelölnek. Adatok forrása: MTA-SZTE ETTK

A kérdőívek egy másik csoportja arra kérte a diákokat és tanárokat, hogy értékeljék, bizonyos értékek mennyire jelentek meg a hagyományos és a videóinterjús tanórán, illetve mennyiben fejlesztették a különböző képességeket. Az alábbiakban pár kivétellel most csak a videóinterjús órák eredményeit vesszük górcső alá ${ }^{4}$ (5. ábra). 


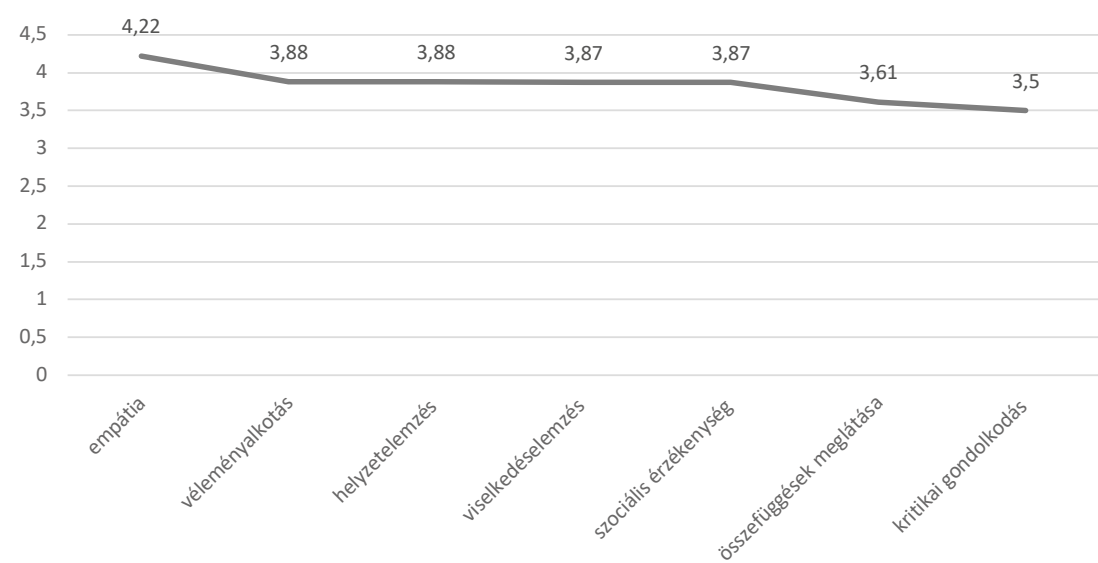

5. ábra. Mennyiben fejlesztette a videóinterjús holokauszt-történelemóra a következöket? Diákok válaszai. 1 = egyáltalán nem fejlesztette, 5 = nagyon fejlesztette. Az 1-5 közötti számok átmenetet jelölnek. Adatok forrása: MTA-SZTE ETTK

Az adatokból jól látszik, hogy a diákok átlagban 4-esre értékelték ezen társadalmilag fontos képességek fejlesztését a tanórának köszönhetően, ami igen jó eredmény. A legmagasabb osztályzatot az empátiás képesség fejlesztése kapta, ezzel igazolva azt az előfeltevésünket, hogy a videóinterjúk alkalmasak a diákok empátiájának növelésére (5. ábra). Az alábbi táblázatban (2. táblázat) a nem videóinterjús órával összehasonlítva is látszik, hogy ennek a készségnek a fejlesztése (ez esetben a kérdöív kérdése nem az 'empátia' szóval, hanem 'az áldozatok szenvedésének átélése' kifejezéssel fogalmazta meg a kategóriát) szignifikánsan magasabb a videóinterjús óra javára.

2. táblázat. Mennyire segitette az áldozatok szenvedésének megértését?

\begin{tabular}{|l|c|c|c|}
\hline $\begin{array}{c}\text { A Holokauszt tanóra mennyire } \\
\text { segítette a számodra... }\end{array}$ & $\begin{array}{r}\text { Azok átlagértékei, AKIKET ÉRDEKEL } \\
\text { A TÖRTÉNELEM }\end{array}$ & Sig. \\
\hline & VIDEÓINTERJÚS & $\begin{array}{c}\text { NEM VIDEÓ- } \\
\text { INTERJÚS }\end{array}$ & \\
\hline $\begin{array}{l}\text { az áldozatok szenvedésének } \\
\text { átélését... }\end{array}$ & 4,33 & 3,54 & Sig. $<0,05$ \\
\hline
\end{tabular}

Adatok forrása: MTA-SZTE ETTK

A kiemelt adat szűkített: a történelem iránt érdeklődő diákok osztályzata alapján. Ha az összes diák válaszát nézzük, ez az adat 4,14, vagyis szintén magasabb a másik típusú órához képest.

A kutatás korábbi szakaszában születő eredmények egyébként szintén alátámasztották azt, hogy a videóinterjús tanórák mindenképpen fejlesztik az empatikus készségeket, és elösegítik az affektív tanulást a történetekhez és túlélőkhöz való személyes kötődés kialakulása miatt (Jancsák, Szőnyi és Képiró, 2019).

Valószínű azonban, hogy a kvantitatív mérés adatait azért fenntartásokkal kell kezelni, mivel nem mindig tünik konzekvensnek, ha máshogy kérdezünk (6. ábra). 
Mezei Mónika: Holokauszt-oktatás multimédiás eszközök segítségével

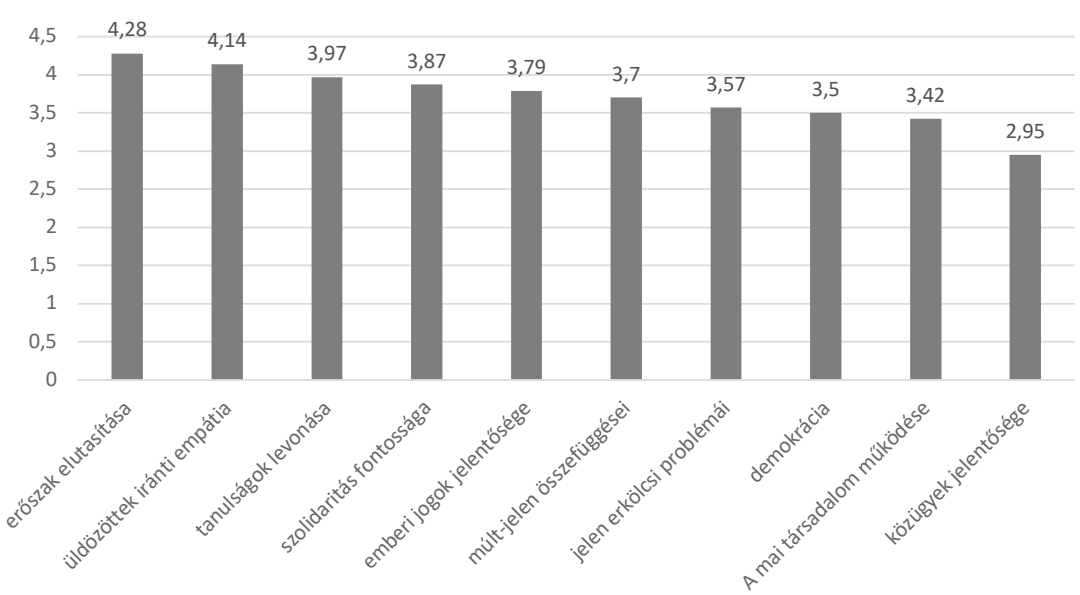

6. ábra. A videóinterjús tanóra mennyire segitette számodra az egyes értékek megerösitését, felismerését vagy megértését. Diákok válaszai. 1 = egyáltalán nem, 5 = nagyon. A közbülsö értékek átmenetet jelölnek. Adatok forrása: MTA-SZTE ETTK

Látható, hogy a legmagasabb osztályzatot az erőszak elutasítása és az empátián alapuló megértés segítése kapta, majd körülbelül egy tartományba esik a tanulságok levonása, a szolidaritás, az emberi jogok és a múlt-jelen összefüggéseinek felismerése. Viszonylag alacsony értékeket kapott a demokrácia értékeinek és a közügyekben való részvétel jelentőségének osztályozása (6. ábra). Az eltérések visszavezethetők több okra is: a tanulók nehezen tudják pontos számokra lefordítani ezen attitüdök értékelését, ebben meghatározó lehet az óra témája, vagy hogy a tanulók nem mindig tudják pontosan értelmezni az egyes fogalmakat, amire rákérdezünk. Összességében azonban láthatjuk, hogy az adott társadalmi értékek és attitüdök fejlesztését és megértését kifejezetten elősegítették a kutatásban szereplő videóinterjús tanórák - legalábbis a tanulók önbevallása szerint.

\section{A kvalitatív mérések eredménye}

A kutatás kvantitatív méréseit kiegészítették fókuszcsoportos beszélgetések tanóránként 3-3 tanulóval. A beszélgetések vezetője nyitott kérdéseket tett fel a diákoknak a tapasztalataikról: mit tanultak, milyen következtetéseket vontak le maguknak, mivel gazdagodtak, mennyire élvezték az órákat és így tovább. A válaszokban a diákok kötetlenül kifejthették a véleményüket, és így szabatosabban, árnyaltabban meg tudták fogalmazni a videóinterjús, illetve a hagyományos órák tanulságait.

Válaszaikban a diákok kivétel nélkül megemlítették, hogy milyen érzelmi hatást gyakoroltak rájuk az interjúk, hogyan éreztek a hallott történetekkel és a túlélőkkel kapcsolatban, és hogy mennyivel közelebb került hozzájuk ezáltal a múltbeli esemény:

„Ha látjuk, hogy ez kezd kialakulni, akkor tegyünk ellene.” (12. oszt.)

„...hogy milyen érzés volt egyes történelmi eseményeket megélni.” (12. oszt.)

„[...arra tanítottak a videóinterjúk,] hogy hogyan kell felismerni a veszélyt” (12. oszt.) 
A korábban már említett IWitness-feladatok elvégzése után kitöltött kérdőívből „A videóinterjúk hozzásegítettek ahhoz, hogy..." nyitott mondat befejezésére érkező jellemző válaszok közül néhány:

„Tisztább képet kapjak arról, hogy milyen volt akkoriban élni. Én személy szerint nagyon szeretem, ha egy idősebb ember mesél az életéről, vagy a felmenői életéről, éppen ezért a nagyszüleimet is gyakran faggatom, hogy meséljenek nekem. Emiatt ezek a videók is nagyon tetszettek." (11. oszt.)

„....az adott helyzetet átélők, vagy rokonaik személyesebb szempontjából is rálássak egy témára, ami lehet, hogy másképp csak tananyagnak tünne." (11. oszt.)

„...átérezzem az interjúalany érzéseit” (11. oszt.)

„Szerintem a videóinterjúk abban is segítséget jelentenek, hogy az emberek sokkal empatikusabbak lesznek, és képesek lesznek meglátni egy-egy (esetleg általuk lenézett, vagy gyülölt) népcsoportnak az emberi oldalát is.” (12. oszt.)

„Jobban megértsem, elképzeljem és átérezzem az emberek akkori helyzetét.” (12. oszt.)

Szó nincs persze arról, hogy a nem videóinterjús órán részt vevők ne találkoztak volna az események emberi oldalával is, de érezhetően jobban fókuszba került mindez a videóinterjús tanórán, ${ }^{5}$ legalábbis a fókuszcsoportos beszélgetések során inkább reflektáltak történelmi tényekkel kapcsolatban felmerült kérdésekre, mint a másik csoport.

A személyes történetek megismerése és a túlélők iránti empátia megerősítette azokat az attitüdöket a diákokban, amelyek a cselekvő magatartás fontosságának felismerését hangsúlyozzák. A társadalom negatív irányú változása jeleinek felismerését, a diszkrimináció tudatosítását, a tolerancia gyakorlását, az egyén és a közösség felelősségét, a kiállást az üldözöttek mellett, a demokratikus jogok fenntartását.

„...meg kell tanulni már egész fiatalon az immunitást kiépíteni [a radikális eszmék ellen]" (12. oszt.)

„...a kitaszítást azt úgy próbálni kéne valahogy [...] szóval a kitaszítást kéne eltaszítani magunktól" (12. oszt.)

Ezt megerősítik az IWitness-feladat esetében megfogalmazott válaszok is: ${ }^{6}$

„Meg kell értenünk, hogy nem a saját jogainkat kell védenünk, hanem a jogok létezését, ugyanis, ha szó nélkül hagyjuk, hogy másoktól elvegyék, akkor már csak idő kérdése, hogy mi következzünk." (12. oszt.)

„Azt hiszem, az a legfontosabb, amit megtanultam ebből a foglalkozásból, az az, hogy ha van választási lehetőségünk, akkor van felelösségünk is abban a döntésben, amit meghozunk." (12. oszt.)

„Immár egy fél évszázaddal később ez már a világ felelőssége, a mi felelősségünk, hogy soha többet ne történhessen ilyen és ehhez hasonló diszkrimináció és genocídium úgy általánosságban.” (12. oszt.) 
„A politikai inaktivitás nagyon drágán fizetendő luxus egy demokráciában vagy egy köztársaságban. Felelős állampolgárként muszáj olyan politikai közeget létrehoznunk, ami az emberség és a józan ész korlátaival állítja meg az ilyen tragédiákat, már a kezdeteknél. Ehhez viszont művelt, politikailag aktív generációkra lesz szükség, akik nem dobják oda másoknak büszkén, hogy én nem politizálok." (12. oszt.)

A videóinterjús tanórákra adott reflexiókban megfigyelhető a felelős állampolgári attitüd kialakulása és annak tudatosítása, hogy mihez vezethet, ha egy állam nem tartja tiszteletben az emberi jogokat, mindezt a többségi társadalom hallgatólagos beleegyezésével (szemlélő hatás) vagy akár aktív közremüködésével. Végül is a történelem tanításának éppen az az egyik, ha nem a legfontosabb célja, hogy a múlt hibáiból tanulva megtanuljunk egy jobb társadalmat felépíteni, és ennek megvalósításához az első lépés éppen saját társadalmi felelősségünk felismerése.

\section{Összegzés}

Előzetes elképzeléseink szerint a videóinterjús tanórák többek között olyan attitüdöket fejlesztenek, mint a felelösség, a szolidaritás, az empátia, az emberi jogok tisztelete. Egyrészt azért, mert feltevésünk szerint a multimédiás eszközök használata mindenképpen élményt nyújt a diákoknak a tanulásban, és ezért hatékonyabb többek között a demokratikus jogok és müködésük megtanítására. Másrészt azért, mert a személyes történeteket és perspektívákat tartalmazó interjúk jobban fejlesztik az empátia, a kritikus gondolkodás, a multiperspektivitás, a véleménynyilvánítás, a demokratikus működés és más, a felelős állampolgársághoz szükséges affektív és kognitív készségeket.

Feltételezéseinket az eddigi kvantitatív és kvalitatív kutatások bizonyos mértékig igazolták. A hagyományos tanórához képest a videóinterjús tanóra jobban felkeltette a diákok érdeklődését, nem csak az óra alatt, de utána is jobban foglalkoztatták őket az ennek kapcsán felvetődő kérdések. A kvantitatív mérések eredményeit óvatosan kell kezelnünk, mert számos nem pontosan meghatározó tényező (a tanulók tudatossága, a tanóra témája, stb.) egyszerre befolyásolhatta a diákok által adott értékelések osztályzatait.

Mindezeket a hiányosságokat azonban a kvalitatív elemzések javíthatják. A mérésekben jelentkező ellentmondások arra is visszavezethetőek, hogy a diákok önbevallásai meglehetősen szubjektív eredményt hozhatnak. Továbbá nem mindegy, hogy a kutatásban részt vevő diákok milyen mennyiségben találkoztak a multimédiás eszközökkel a kutatás tárgyát képező órákat megelőzően. Azok a diákok, akik, ha esetleg nem is ebben a témában, de már sokszor találkoztak videóinterjúkkal, jóval tudatosabbak lehetnek azokkal szemben, akik életükben elöször, mindössze egy ilyen órán vettek részt - ezek a különbségek torzíthatják az eredményeket. Azt is tekintetbe kell vennünk, hogy ebben a kutatásban még csak részeredményekröl beszélhetünk a mintákban részt vevők alacsony száma miatt.

A tanórák eredményességét a fentieken kívül még számos tényező befolyásolhatja. Egyetlen tanóra nem alkalmas a kompetenciák és készségek fejlesztésére, ezért is lenne üdvös, ha a multimédiás eszközök használata elterjedne, és a diákok nem csak kivételes alkalmakkor találkoznának az interjúkkal, hanem ez szerves részét képezné az oktatásuknak.

A pedagógus személyisége és módszertani jártassága szintén fontos tényező. Valószínüleg nem önmagában a videóinterjúk használata teremti meg a felelős és tudatos állampolgárságra nevelés alapjait. Ha egy tanár, illetve általában egy adott iskola intézménye és tantestülete a mindennapi müködésében nem enged teret a diákok szabad 
véleménynyilvánításának, ha a tanár túlságosan autoriter személyiség, aki nem tartja tiszteletben a diákok jogait, és nem tanítja meg őket felelősen gondolkodni, akkor nem sok esély van rá, hogy hitelesen tudja közvetíteni ezeket az értékeket. Hasonlóképpen fontos a megfelelő módszertan alkalmazása a videóinterjúk feldolgozásakor. Nem szerencsés például csak illusztrációnak használni az interjúkat anélkül, hogy megfelelő feladatokat készítenénk a multimédiás eszközökhöz. Ehhez elengedhetetlen a tanárok megfelelő felkészítése, képzése.

Záró gondolatként azt fogalmaznám meg az eddigi kutatással kapcsolatban, hogy érdekes lenne egy 10-15 évvel későbbi utánkövetés olyan volt diákokkal, akik gyakran részesültek multimédiás oktatásban, hogy hosszú távon igazolódik-e, hogy ezek a diákok valóban cselekvőbben vesznek részt a közéletben vagy a maguk közösségének alakításában. Valószínűleg ehhez nem elegendő egy-két multimédiás eszközöket felvonultató tanóra, még az sem, ha a történelem vagy bármely más szaktárgy tanítása során viszonylag gyakran kerülnek elö videóinterjúk. Az lenne az ideális, ha a kívánatos társadalmi értékeket (tolerancia, empátia, kritikai gondolkodás) az egész iskolarendszer tudná közvetíteni. A videóinterjúk használata elörelépést jelenthet a tudatosság felé, segítségükkel megtaníthatjuk diákjainknak legalább felismerni a fontos társadalmi értékeket, és fejleszteni bennük az önreflexiót, a kritikai gondolkodást.

\section{Támogatás}

A tanulmány megjelenését a Magyar Tudományos Akadémia Tantárgy-pedagógiai Kutatási Program támogatta.
A pedagógus személyisége és módszertani jártassága szintén fontos tényezó. Valószínúleg nem önmagában a videóinterjúk használata teremti meg a felelós és tudatos állampolgárságra nevelés alapjait. Ha egy tanár, illetve általában egy adott iskola intézménye és tantestülete a mindennapi múködésében nem enged teret a diákok szabad véleménynyilvánitásának, ha a tanár túlságosan autoriter személyiség, aki nem tartja tiszteletben a diákok jogait, és nem tanítja meg óket felelósen gondolkodni, akkor nem sok esély van rá, hogy hitelesen tudja közvetíteni ezeket az értékeket. Hasonlóképpen fontos a megfeleló módszertan alkalmazása a videóinterjúk feldolgozásakor. Nem szerencsés például csak illusztrációnak használni az interjúkat anélkül, hogy megfeleló feladatokat készitenénk a multimédiás eszközökhöz. Ehhez elengedhetetlen a tanárok megfeleló felkészitése, képzése.

\section{Irodalom}

Bage, G. (1999) Narrative Matters - Teaching and Learning History through Story. Falmer Press.

Ecker-Angerer, M. (2018). What exactly makes a good interview? Educational work with videotaped testimonies at erinner.at. In Dreier, W., Laumer, A. \& Wein, M., Interactions: Explorations of Good Practice in Educational Work with Video Testimonies of
Victims of National Socialism. Stiftung Erinnerung, Verantwortung und Zukunft. 181-190.

Farmer, A. \& Cooper, C. (1998). Storytelling in History. In Hoodless, P. (szerk.), History and English in the Primary School. Routledge. 35-51. DOI: 10.4324/9780203014028-13 
Husbands, C. (1996). What is History Teaching? Open University Press.

Jancsák Csaba (2018). Szemtanúkkal készült videointerjúk alkalmazása valamint hozzáadott értéke a történelem és állampolgári ismeretek tanításásban. In Bánréti Zoltán, Jancsák Csaba, Kósa Maja \& Képiró Ágnes (szerk.), ,Félidőben”-Eredmények és perspektívák. Belvedere Meridionale - MTA-SZTE ETTK. 13-18.

Jancsák, C., Szőnyi, E. \& Képiró, Á. (2019). The impact of video testimonies in Holocaust education in Hungary. International Journal of Research on History Didactics, History Education, and History Culture. (JHEC), 161-179.

Keating, J. \& Sheldon, N. (2011). History in Education: Trends and Themes in History Teaching. In Davies, I. (szerk.), Debates in History Teaching. Routledge.

Kojanitz László (2020). A történelmi interpretáció és az oral history az oktatásban. Belvedere Meridionale, 32(4), 16-33. DOI: 10.14232/belv.2020.4.2
Körber, A. (2011). German History Didactics: From Historical Consciousness to Historical Competencies - and Beyond? In Bjerg, H., Lenz, C. \& Thorstensen, E. (szerk.), Historicizing the Uses of the Past: Scandinavian Perspectives on History, Culture, Historical Consciousness and Didactics of History Related to World War II. Transaction Publishers. 145-164. DOI: 10.1515/transcript.9783839413258.145

Levstik, L. S. \& Barton, K. C. (2011). Doing History: Investigating with Children in Elementary and Middle School. Routledge. DOI: 10.4324/9781315818108

Mezei Mónika (2019). Az IWitness online digitális oktatási platform. http://ujkor.hu/content/az-iwitness-online-digitalis-oktatasi-platform Utolsó letöltés: 2021. 03. 29.

Nahalka István (2013). Konstruktivizmus és nevelés. Neveléstudomány, 4, 21-33.

Nora, P. (1996). Realms of Memory: Rethinking the French Past. Columbia University Press.

\section{Jegyzetek}

1 https://sfi.usc.edu/ Utolsó letöltés: 2021. 03. 29.

2 https://www.zachor.hu/ Utolsó letöltés: 2021. 03. 29.

3 https://iwitness.usc.edu/SFI/ Utolsó letöltés: 2021. 03. 29.

4 A két típusú órát tkp. nem tudjuk összehasonlítani a diákok adatai alapján, mivel egy diák csak az egyik órán vett részt.

5 A kettőnek, azaz a történeti hüségü elemzésnek és az empatikus megközelítésnek egyáltalán nem kell kizárnia egymást, sőt. A tényszerű adatok bizonyos fokú ismerete nélkül a diákokat túlterhelhetjük érzelmekkel, az érzelmek nélküli tényadatok közlése pedig egyrészt száraz és érdektelen lehet, illetve elidegenítheti a diákoktól a témát. (Ecker-Angerer, 2018. 188-189.).

6 https://iwitness.usc.edu/sfi/Activity/ A holokauszt szerepei c. multimédiás tananyag válaszai. Utolsó letöltés: 2021. 03. 29.

\footnotetext{
Absztrakt

A Dél-kaliforniai Egyetem Soá Alapítványának videóarchívuma közel 53000 holokauszt-túlélő, embermentő és táborfelszabadító interjúját tartalmazza, amelyek felhasználása új távlatokat nyitott meg a holokauszt oktatásában. Az alábbi tanulmányban szó esik a videóinterjúk használatának pedagógiai céljairól és előnyeiről a hagyományos oktatáshoz képest. Az MTA-SZTE Elbeszélt Történelem és Történelemtanítás Kutatócsoport által végzett kutatás azt vizsgálja, hogy a történelmi emlékezet és a multimédiás eszközök beemelése a 20. századi traumák oktatásában milyen képességeket és attitüdöket tud kialakítani a diákok oktatása során. A kvantitatív és kvalitatív mérések eddigi részeredményei is arra utalnak, hogy az empátia, a társadalmi tolerancia és szolidaritás, a felelősségérzet és a kritikus gondolkodás készségeinek fejlesztésére a multimédiás eszközök kiválóan alkalmazhatók.
} 